\title{
The Correlations between County Economy and Rural Surplus Labor -Taking CangZhou City of Hebei Province as Example
}

\author{
Hui Xing \\ School of Economics and Management \\ Hebei University of Technology \\ Tianjin, China \\ gdzymxh@126.com \\ Xueyan $\mathrm{Hu}$ \\ School of Economics and Management \\ Hebei University of Technology \\ Tianjin, China \\ 870583732@qq.com
}

\author{
Suying Gao \\ School of Economics and Management \\ Hebei University of Technology \\ Tianjin, China \\ sue2007@hebut.edu.cn \\ Jianzhao Liu \\ School of Economics and Management \\ Hebei University of Technology \\ Tianjin, China \\ 85292260@qq.com
}

\begin{abstract}
Being as a typical agricultural city of Hebei Province, Cangzhou City is bearing large employment pressure from rural surplus labor. So how to solve rural surplus labor becomes the key problem. Some experiences show that county economy can enhance the level of the transfer of rural surplus labor, which means there is an obvious correlation between them. Therefore based on the related literature at home and abroad, the paper makes an empirical study on the relationship between county economy and rural surplus labor by correlation and regression analysis. Results show that there is an obvious correlation between them, namely county economy offers employment opportunity to rural labor and increases the peasants' income. Meanwhile, the transformation of surplus rural labor promotes county economy development. Finally, the paper puts forward some feasibility suggestions and reference to various government functional departments and the academia.
\end{abstract}

Keywords- rural surplus labor; county economy; Cangzhou city; regression analysis

\section{INTRODUCTION}

"Three agricultural problems" are paid more and more attention. During the agricultural problems, the peasant problem is the key demanding to resolve. Experiences have shown that the development of county economy is helpful to solve the problem; the level of county economy plays a role in promoting the transfer of surplus rural labor. By interviewing part of Cangzhou city, the authors have certain knowledge of some actual condition of Cangzhou city. Cangzhou city is neighbor to Tinajin and Beijing. In recent years through the development of its county economy and small town economy, it has absorbed a large number of rural surplus labors, but the employment pressure from rural

The research is supported by the Key Program of China National Natural Science Foundation (No. 71172153), Arts \& Social Science Foundation of The Ministry of Education (No. 09YJA790058), Philosophical and Social Science Foundation of Tianjin (No. TJYY08-1-037) surplus labor is severe. How to solve rural surplus labor is still the key problem. So this paper tries to have an empirical study on the relationship between the growth of county economy and the transfer of rural labor taking Cangzhou city in order to analysis and discuss the relative questions. And finally the authors hope to provide some theoretical and practical help in the process of its economic development.

\section{LITERATURE REVIEW}

From the classic economics period, foreign scholars have maken some studies about the transfer of rural labor. Although Adam Simth (1776), William Petty (1690) and David Ricardo (1817) discussed this issue from different perspectives, they all studied on the labor flow and related problems. Later Lewis (1954), Kuznets (1966), Todaro (1969), Schultz (1976), Chenery (1975) and other economics also explored the issue from different perspectives. Then development economics constructed a basic theoretical framework of labor transfer, and these theories together form the basic theory of labor transfer. Chinese scholars have done some researches about the labor transfer of our country based on those western theories.

In 2002, Peigang Zhang in his paper of “agriculture and industrialization" proved some problems in industrialization process of agricultural countries. His theoretical framework is essentially consistent with Lewis' dual economic theory. In 2004, Zhao Guodong in the paper of "A Study on the Transfer of Surplus Labors in Rural Areas and Employment Problems in both Urban and Rural Areas"described that rural surplus labor is the necessary conditions of rapid development of private economy, while the rapid development of privately owned economy also provide more employment and employment opportunities for the transfer of rural surplus labor. In 2007, Wang Chunlei in his paper “'Urbanization' development pattern choice and countryside surplus labor force shift" showed that the development of county economy is the effective way to promote the transfer 
of surplus labor. In 2005, Li Kaqi in his paper "Study on the Transfer of Rural Surplus Labor by County Economy Development" pointed out that the development of our county economic exits some problems and put forward clearly that county economy is the inevitable choice of the transfer of rural surplus labor from different aspects such as the transfer of rural surplus labor, transfer structure, limiting factors. Chen Zhaoxing (2007) in her paper of "The Research on the Country Economy Absorbing Surplus Rural Labor"did a a whole research on the current transfer of rural surplus labor and made the level of county economic development from the national perspective, then drawn the conclusion that there is a very big relations between county economic and transfer of rural surplus labor.

Through the above related literature we can see that effective transfer of rural labor is helpful to promote the growth of county economy, and it is conducive to solve three agricultural problems. However, most of the studies are mostly concentrated in the nationwide, while there is lack of empirical research specific to the county-level cities. So it is what this paper is trying to do.

\section{CURRENT SITUATION OF COUNTY ECONOMIC AND SURPULS RURAL LABOR OF CANGZHOU CITY}

A. Current situation of Country economic of Cangzhou city

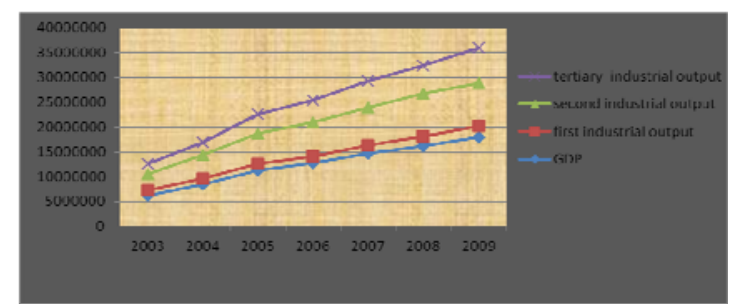

Figure 1. Economic growth of Cangzhou city (ten thousand)

In twenty-first Century, Economy of Cangzhou city has entered a rapid development stage. From Fig. 1 we can see that economy of Cangzhou is rapidly rising in recent years, GDP increased from 62.88 billions yuan in 2003 to180.1 billions yuan in 2009, a year-on-year increase of 14.5\%, 2.3 percentage points higher than the growth rate of the whole province. Among them, the first industrial added value reached 25.26 billions yuan, compared to the growth of GDP; it is 6 percent point higher than last year. The second industrial added value reached 111.71 billions yuan, having an increase of $14.1 \%$; the tertiary industry added value reached 83.33 billions, having a growing of 17.4 percent. Three-industry structure is $11.5: 50.7: 37.8$. Along with the second and third industries grow sturdily, small and mediumsized enterprises gradually expand the scale and the demanding of rural labor is increasing year by year. At the same time it also promoted the development of county economy.

\section{B. Current situation of rural surpuls labor of Cangzhou City}

From Fig. 2 and Fig. 3 we can see that the population of Cangzhou city increased year by year but rural population proportion decreased. At the same time, the peasant income also rises somewhat. Peasant Per Capita income increased from 2549 yuan of 2002 to 4599 yuan of 2009. And in the structure of income, in 2002 agriculture took the share of income for $47.6 \%$, while non-agricultural income has exceeded agricultural income, accounting for $52.4 \%$; then in 2009, the non-agriculture income in the proportion of Peasant Per Capita income continues to rise, reaching at $59.8 \%$. It can be predicted that non-agricultural income would have more impact on farmers' income increasingwith the transfer of rural surplus labor.

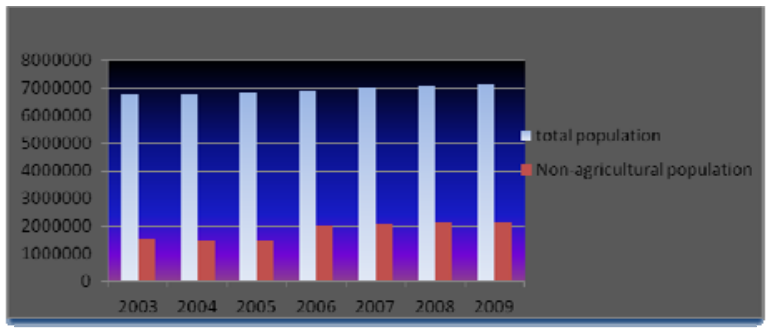

Figure 2. Population change of Cangzhou city

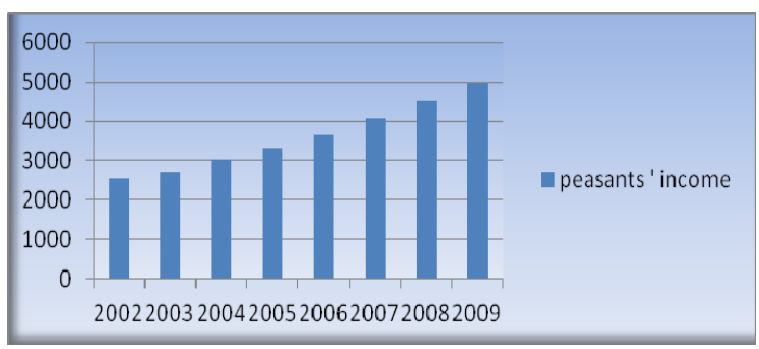

Figure 3. Peasant per capita income of Cangzhou city (unit: yuan)

\section{AN EMPIRICAL ANALYSIS ON THE RELATIONSHIP} BETWEEN COUNTY ECONOMY AND RURAL SURPLUS LABOR OF CANGZHOU CITY

\section{A. Current situation of rural surplus labor of Cangzhou city}

There are number of ways to calculate surplus rural labor. Because Wang Ling and Hu Haozhi's estimation method is not only easy to acquire the needed data, but also can simply compute the amount of surplus rural labor in cities and counties, moreover the calculation results can make horizontal comparison and the operability is strong, so this paper chooses its estimation method to deal with the relative data of Cangzhou city in 2009. The formula is as follows:

$$
L=F \times S
$$

In the formula, $\mathrm{L}$ is the amount of strength of agricultural surplus labor; F stands for the labor of 
agriculture, forestry, animal husbandry and fishery which means total number of agricultural labor, $\mathrm{S}$ stands for agricultural surplus rate. The calculation formula of agricultural surplus labor rate is as follows:

$$
S=L-G
$$

In the formula, $\mathrm{L}$ is the first industry labor share of industry labor aggregate proportion; $G$ is the first industry production value occupies GDP proportion.

Table 1 rural surplus labor of Cangzhou

\begin{tabular}{|c|c|c|c|c|}
\hline region & F & G & surplus labor & S \\
\hline Xinhua & 0.54 & 0 & 4336 & \\
\hline Yunhe & 0.58 & 0.01 & 11672 & \\
\hline Cangxian & 0.25 & 0.14 & 10053 & 0.148 \\
\hline Qingxian & 0.33 & 0.19 & 9335 & 0.141 \\
\hline Dongguang & 0.42 & 0.22 & 13904 & 0.144 \\
\hline Haixing & 0.59 & 0.23 & 22232 & 0.312 \\
\hline Yanshan & 0.47 & 0.14 & 31587 & 0.3 \\
\hline Suning & 0.37 & 0.19 & 13347 & 0.155 \\
\hline Nanpi & 0.65 & 0.23 & 43731 & 0.374 \\
\hline Wuqiao & 0.57 & 0.34 & 19963 & 0.452 \\
\hline Xianxian & 0.43 & 0.23 & 23522 & 0.318 \\
\hline Mengcun & 0.5 & 0.09 & 18369 & 0.295 \\
\hline Botou & 0.29 & 0.14 & 10826 & 0.271 \\
\hline Rrenqiu & 0.22 & 0.04 & 11072 & 0.118 \\
\hline Huanghua & 0.23 & 0.12 & 4697 & 0.155 \\
\hline Hejian & 0.24 & 0.11 & 12955 & 0.135 \\
\hline
\end{tabular}

B. Analysis on the relationship between county economy and rural surplus labor

This paper selects the data of 14 counties of Cangzhou city in 2009. And the selected variables are GDP per capita (AGDP) and surplus labor rate (PLAB). The former represents the growth of county economy and the latter is the transfer of rural surplus labor level. The data is shown in Table 2.

Table 2 per capita GDP and surplus labor rate of each country's

\begin{tabular}{|c|c|c|}
\hline region & the per capita GDP & surplus labor rate \\
\hline Cangxian & 21439 & 0.148 \\
\hline Qingxian & 25631 & 0.141 \\
\hline Dongguang & 23017 & 0.144 \\
\hline Haixing & 11471 & 0.312 \\
\hline Yanshan & 15578 & 0.3 \\
\hline Suning & 25530 & 0.155 \\
\hline
\end{tabular}

\begin{tabular}{|c|c|c|}
\hline Nanpi & 14587 & 0.374 \\
\hline Wuqiao & 14200 & 0.452 \\
\hline Xianxian & 17152 & 0.318 \\
\hline Mengcun & 16535 & 0.295 \\
\hline Botou & 17015 & 0.271 \\
\hline Renqiu & 38365 & 0.155 \\
\hline Huanghua & 31070 & 0.118 \\
\hline Hejian & 28555 & 0.135 \\
\hline
\end{tabular}

Then we have a research into the relation between county economy and rural surplus labor using Eviews software. The results are in Table 3 and Table 4.

$$
\text { Table } 3
$$

\begin{tabular}{|c|c|c|c|}
\hline R-squared & F-statistic & \multicolumn{2}{|c|}{ Durbin-Watson stat } \\
\hline 0.707 & 29.07 & \multicolumn{2}{|c|}{1.29} \\
\hline \multicolumn{4}{|c|}{ Table 4 } \\
\hline & Coefficient & t-Statistic & Prob. \\
\hline c & 35137.83 & 12.59716 & 0 \\
\hline plab & -58506.59 & -5.391594 & 0.0002 \\
\hline
\end{tabular}

We can see from above, a equal 0.05 is considered as significant test level, the prob values are smaller than the confidence level, they are in the interval of rejection; and from $\mathrm{T}$ test value, critical value under 0.05 significant level of degrees with the degree of freedom 13 is 2.1604, t-test value of 12 and -5 are greater than the adjacent values, so it can be connected with suffer; to be addition the slope indicates that per 0.1 percentage point reduction of rural surplus labor rates, per capita GDP will increase 58 yuan.

\section{AGDP=35137.83-58506.59PLAB}

Moreover, we can see from the regression results, the larger the coefficient of determination is, and the better the equation is fitted. The coefficient of determination of the model is 0.7 which means per capita GDP changes of $70 \%$ can be explained by the surplus rural labor rate changes.

Above all, the inspection shows that there is significant difference between the growth of county economy and the transfer of rural surplus labor.

\section{The influencing factors on growth of county economy of Cangzhou city}

There are many factors to impact the economic growth in macro. And the index system is complex systems composed of a plurality of indexes of mutual connection, mutual comply with statistical indexes. When selecting the variables, we just take the growth of county economy level into consideration to let the index reflect the real growth of county economy level, and consider the gross index while considering relative index. It includes gross domestic product (GDP), above-scale industrial output value (SC), population (P), various financial institutions deposit at the end of the year (wan yuan) (TS), per capita urban and rural dweller 
deposit balance (XJ).

According to the evaluation index system, the model takes 5 evaluation index data of 17 counties (city, area) of Cangzhou City in 2009, using Eviews software analysis to examine it. The results are in Table 5.

$\mathrm{R} 2=0.988$ means the index can be used to analyze the questions under study. Population ( $\mathrm{P}$ ), at the end of the year, various financial institutions deposit ( yuan ) ( TS ), per capita urban and rural dweller deposit balance( XJ ) Prob. were significantly lower than the level of confidence which mean it is acceptable; although the scale above gross value of industrial output ( SC ) prob. slightly higher confidence level, but the results of t-statistic test is effective. So it can also be considered acceptable.

\begin{tabular}{|c|c|c|c|}
\hline & Coefficient & t-Statistic & Prob. \\
\hline C & -569867.3 & -5.707987 & 0.0001 \\
\hline P & 1.218836 & 6.206753 & 0.0001 \\
\hline SC & 0.107954 & 1.932834 & 0.0794 \\
\hline TS & 0.331107 & 4.132499 & 0.0017 \\
\hline V & 294819.1 & 7.38111 & 0 \\
\hline
\end{tabular}

According to the above analysis result, we can reach a function about the economic development of 17 counties of Cangzhou City.

\section{CONCLUSION AND SUGGESTION}

\section{A. Conclusion}

There is a strong relation between Per capita GDP and labor surplus labor rates, and they are negatively associated which means the higher level county economy development, the less surplus labor, then the capacity for county economy to absorb rural surplus labor force is stronger. The lower of county economy development leve, the weaker of rural surplus labor is absorbing.

The development level of county economy is much closely relative with the population, the number of scale above enterprise, financial institutions and residents deposit. And they are key factors to promote economic growth. The nearly transfer of residents makes a good strengthen to the influencing development, and then promotes the growth of county economy.

\section{B. Suggestions}

1) Optimize industrial structure. Seeing from the current development of county economy, the relatively backward in industrial structure is an important factor to strict the development of county economy of Cangzhou city. In order to resolve the issue, the government should strengthen the support and protection measures to agriculture, promote the development of labor-intensive enterprises and develop the tertiary industry so as to accelerate the advantage for its capability of absorbing Labor Force.

2) Strengthen and improve the quality of labor. From the current rural labor of science and technology quality and occupation ability, strengthening rural basic education and occupation education is a long term work. Therefore, it is necessary to implement compulsory education, at the same time to adhere to the science and technology, to vigorously develop the secondary skills training and create high quality of higher occupation education and try building and talent environment for attracting talents.

3) Increase the financing form. At present, small and medium-sized enterprises are not only absorbing rural surplus labor but also promoting the growth of county economy. So in the field of corporate finance, the financial sector should actively develope kinds of credit products and financial products to adapt to small and medium-sized enterprises and the country economy, for the development of small and medium-sized enterprises provide a full range of financial services, to promote small and medium enterprises to health, rapid development.

\section{REFERENCES}

[1] Dale W. J. Surplus agricultural labor and development of a dual economy [J].Oxford Economic Papers, 1967, 19(3): 288-312

[2] Huaiyue, Wang. County economy development of China [M]. Shanghai people's publishing house, 2001.

[3] Junjie, Liu. County economy development and small town construction [M]. Beijing social sciences documents publishing house, 2005.

[4] Kaqi, Li. Study on the Transfer of Rural Surplus Labor by County Economy Development[D].china university of geosciences, 2005

[5] Fu Yong.The influence of human capital investment on the surplus rural labor's transition----a study on population floating and labor market[J]. Population and economics, 2004.

[6] Zhaoxing, Chen. The researchon the country economy absorbing surplus rural labor[D]. Tianjin, Hebei university of technology, 2007.

[7] Chenwen, Ma. Zhang Donghui. developing economics[M]. Higher education publishing house, 2007.

[8] Yaochu, Ling. Country economy developing strategy[M].Shanghai xuelin publishing house,2005.

[9] Chunlei, Wang. Urbanization development pattern choice and countryside surplus labor force shift[J]. Journal of baoji university of arts and sciences,2007(3).

[10] Cangzhou economic statical yearbook from 2003 to 2010.

[11] Jinxia LI, Xueshi, QIN The path selection of countryside surplus labor transfer of Hebei Province [J]. Economy and Management, 2006, 20(7):26-28

[12] Harris, J. R. Migration unemployment and development: a twosector analysis [J]. American Economic Review, 1970, 60(1): 126-42.

[13] Arthur, L, W. Economic development with unlimited supplies of labour[J]. The Manchester School , 1954,22(2):139-191.

[14] Thomas, G. R.What's happening to China's GDP statistics? [J]. China Economic Review, 2001,12(4): 298-302.

[15] Solinger, D, J. Citizenship issues in China's internal migration: comparisons with Germany and Japan[J]. Political Science Quarterly, 1999, 114( 3): 455-78. 